\title{
The Process The Formation of The Collective Leadership on The Corruption Eradication Commission
}

\author{
Muslimin. A* ${ }^{a *}$ Yuli Andi Gani ${ }^{\mathrm{b}}$, Suryadi ${ }^{\mathrm{c}}$, Choirul Saleh ${ }^{\mathrm{d}}$ \\ ${ }^{a b c d}$ University of Brawijaya, Malang, East Java, Indonesia
}

\section{ARTICLE INFORMATION}

\section{Article history:}

Data submission : 07 July 2020

$1^{\text {st }}$ revision: 07 December 2020

Accepted: 05 May 2021

Available online: 31 May 2021

Keywords: collective leadership, KPK, corruption

\section{ABSTRACT}

This article was written based on the findings of research that examines the process of formation of collective leadership implemented by the Corruption Eradication Commission (Komisi Pemberantasan Korupsi: KPK) in Indonesia during its inception in 2003 until the end of the leadership of Abraham Samad 2015. The results of the study indicate that the KPK's collective leadership was gradually formed through several stages can be identified in 3 development cycles. The first stage is a pioneering cycle that requires prerequisites for the formation of collective leadership in order to operate the leadership mechanism in the KPK's organizational structure. Second, the critical cycle, namely the operational trials of collective leadership that have the opportunity to succeed or fail. This cycle is characterized by collaboration between structures in the collective decision making process. Third, the operational stabilization cycle, is a stage of development that leads to the cohesiveness of KPK members and results in superior level of performance.

2021 FIA UB. All rights reserved.

\section{Introduction}

Leadership is a form of interaction between leaders and subordinates in the framework of moving the organization to realize short and long term achievements. The form of leadership interaction determines the effectiveness of an organization's success in achieving its grand goals.

This form of leadership is often 'discovered' on the journey, not shaped or planned. When an organization is at the beginning of formation, leadership is carried out in a trial and error situation. It takes the suitability of the form of leadership with the task and authority to face external challenges that are pressing and difficult to predict so that the organization is able to more effectively achieve its goals. The KPK is an exception, its form of leadership has been 'determined' by law. While the assignments are faced very heavily, namely the eradication of corruption. That is why the KPK leadership phenomenon needs to be investigated, especially in aspects of the specific leadership formation process.

* Corresponding author. e-mail: muslimin.msi63@gmail.com
The task as well as the KPK's goal is to eradicate corruption. Throughout its history the Indonesian people have never been free from the phenomenon of corruption. Even more developed along with the achievements of economic development both in the era of President Soekarno's leadership (1945-1967), and especially in the era of the New Order government brought by President Soeharto (1967-1998).

A total of 7 (seven) anti-corruption institutions have been formed and carry out the task of eradicating corruption. But always failed. The failure was caused by the organizational format and form and mechanism of leadership in various corruption eradication institutions that were not balanced to face pressing external challenges. In addition the failure occurred because its position is not independent of other state institutions, especially the president. Likewise, the foothold of its existence is not based on laws so that it is vulnerable to dissolution.

The Corruption Eradication Commission (KPK) was formed on December 29, 2003 based on Law number 30 of 2002 concerning Corruption Eradication Commission. This law stipulates that the KPK is 
independent, not accountable to the president or to other high institutions. The KPK is only responsible to the people of Indonesia. Its task is to eradicate corruption with the authority of the superbody, which is multi-authority which includes the authority of investigation, investigation and prosecution. This is not possessed by other law enforcement agencies such as the police or prosecutors. In addition, KPK leaders are plural, namely 5 (five) people to lead collectively. This collectivity in leadership is a new phenomenon in state institutions in Indonesia, so it is interesting to study and research.

\section{Theory}

Understanding leadership can be understood together with the understanding of leaders. The leader is a person or group of people who behave in the role of directing or controlling members of the organization to carry out activities by cooperating with each other in an effort to achieve common goals. The definition of leader has been more personal, that is, someone who holds a position as a leader or someone who is followed by many people in facing life's problems in society, as stated by Ebegbulem who formulated the concept of leader as, "an individual appointed to a job with authority and accountability to achieve the goals and objectives of society" (Ebegbulem, 2012).

Meanwhile somewhat different from Ebegbulem above are Rivai and Mulyadi who explained the understanding of the leader from the formal position of the leader. For Rivai and Mulyadi, leaders are members of a group that are given a certain position and are expected to act according to their position (Rivai \& Mulyadi, 2011).

After reviewing the various definitions put forward by many experts, Yukl concluded that the leader was someone who deliberately carried out the process by emphasizing his influence strongly on others to guide, structure, facilitate activities and relationships within groups or organizations (Yuki, 2007).

Related to the concept of leader is leadership. Robins traces expert opinions to get a comprehensive understanding of leadership. Robbins states leadership is the ability to influence groups towards achieving goals (Robins, 2002).

Robbins's opinion was in line with Kartono who emphasized the leader in terms of his nature or strengths so that he was able to direct and influence others to carry out activities in order to achieve goals (Kartono, 2013). Meanwhile Pasolong, explained the definition of leadership as the ability to give constructive influence to others to make a cooperative effort to achieve the planned goals (Pasolong, 2010).

The development of this latest leadership theory found that the leadership role is not only carried out by a leader but can be done by several leaders or several team members. The understanding of this leader is more "collective" because the figure of the leader is not formulated individually as conventional leadership and leadership concepts which put the leadership function only on the roles of an individual formal leader. Collective leadership is known as collective leadership. Besides developing theories of leadership that are also collective with diverse terminology, so that the term collective leadership is often exchanged with the terms team leadership, share leadership or distributive leadership (Crutchfield \& Grant, 2010), or collaborative leadership (Archer \& Cameron, 2009), and multyple leadership (Friedrich et al., 2009). The difference in this leadership model lies in the emphasis of the study. On collective leadership the emphasis lies on the dynamics of the collective role in the leadership process. Friedrich often also replaces the term collective with multyple to emphasize interactional processes between people who are both carrying out leadership roles in different fields but are still in the same team or organization. Whereas the Team Leadership emphasizes the effectiveness of the team in improving performance caused by cooperation between variations in competencies or functional expertise of team members.

When an institution or organization faces challenges from external parties in an uncertain situation, change can be sudden, ambiguous, and discontinuity, and difficult to predict. Then the organization or institution means that it is facing a threat that will weaken and even eliminate its existence. There is no other way but to deal with it by increasing organizational performance and leadership effectiveness.

During this time the study of the phenomenon of leadership uses more conventional perspectives which see that all aspects of the role of leadership are more centered on the person of the leader or formal leader. Whereas in reality leadership roles in organizations are more often played alternately (Share LeadershipDistributive Leadership) between team members, both in their capacity as formal and informal leaders in the sense that members act as leaders in certain cases or situations.

Shifting the leadership role from one person to another in various levels is often rooted in the functional expertise possessed by each person. When an organization faces a problem or threatening situation, it will appear to the person who has expertise that is coherent with the situation and problem faced by the organization to act as a leader (Friedrich et al., 2009).

In other words leadership processes are rarely played on an individual level by formal leaders. Because leadership is a complex phenomenon involving various individuals in the organization and each person can act as a leader when the situation places the capacity of his expertise on the problems facing the organization.

Collective leadership theory emphasizes its conceptual existence in the processes of distributing leadership roles to individual team members, depending on the emergence of the challenges of the situation and the problems faced. This conditions the leadership situation will place individuals who have competence and expertise in accordance with the situation and problem, immediately go forward to take the leadership role to solve the problems faced. And other individuals retroactively provide a place according to their function. Then its role recedes immediately when the development of the situation requires other expertise.

The process of sharing and distributing roles is easy because in collective leadership there is a shared 
understanding of the need to exchange roles between team members, both as subordinates and leaders.

In general the dynamics of collective leadership are more often found in the area of top management, characterized by the existence of integrated behavioral patterns in carrying out different leadership roles between one person and another in the team (Friedrich, 2009). That is why the dynamics of collective leadership process are very complex, occur in a multi-level area, and the dynamic processes give rise to the distribution of cross-leadership leadership roles among the skills and expertise possessed by team members.

\section{Research Method}

This research was conducted in the perspective of qualitative research in the type of study library research. The reason for using this type of research is due to the fact that the KPK collective leadership research setting in the era of Taufiequrachman Ruki's leadership (20032007), Antasari Azhar (2007-2011) until the era of Abraham Samad's leadership (2011-2015) has ended and finished more than 5 (five years ago. This makes it impossible to use a research approach with the type of field research that relies on extracting data by interviewing and observing. In addition, the use of study libraries in this research is the quantity of information that is pretty much documented in various forms. Primary data were obtained from various sources such as the perpetrator's daily record, the KPK's annual report. In addition, secondary data was obtained from various magazines, newspapers, reports, and many literary sources that examined leadership and problems that occurred at the KPK during the 2003-20015 period.

The analysis was carried out through 4 stages, namely (1) Identifying text content information to some general themes and sub themes. Stage (2) is the process of describing the themes and sub themes that are found. Stage (3) classifies and categorizes themes into a whole concept. Classification and categorization that were successfully built into a concept will be described in a complete and clear manner so as to be able to describe sub phenomena in a particular theme. Stage (4) is a proccess to connects the concepts in the description of the connectivity between the concepts in order to obtain a complete theoretical explanation of the phenomenon of the KPK's collective leadership mechanism. Stage (4) can be referred to as the process of theorization, which is to formulate an explanation of the relationship between logical concepts so that a comprehensive and comprehensive explanation of the phenomenon under investigation is obtained.

\section{Results}

Below this is explained the development of the existence of the Corruption Eradication Commission (KPK) institution from its inception which is still applied to personal leadership patterns, gradually metamorphosing towards the formation of collective leadership. Beginning with the style of the KPK's first leader, Taufiequrachman Ruki (2003-2007), a retired police general as a pioneering era of collective leadership. Antasari Azhar's era of leadership continued (2007-2011), it can be said as a critical era in the formation of collective leadership. And in the era of leadership of Abraham Samad (2011-2015) is an era of strengthening the form of collective leadership.

Taufiequrachman Ruki's leadership era was a pioneering period to begin implementing collective leadership. The process can be said to be try and error. As the first chairman of a new law enforcement institution, Taufiqurrahman Ruki's leadership actions tend to be patterned on personal leadership as the pattern of leadership in almost all government institutions. There is a strong influence on the background of previous work experience. Taufiqurrahman Ruki came from the police whose leadership was centered on the National Police chief with a very hierarchical mechanism of work. Likewise, four other members of the KPK leadership, having experience in previous institutions where they worked, can be said to apply personal leadership.

During the first 2 years of Taufiqurrahman Ruki leadership could be said to be a pioneering stage in the formation of the KPK institution from nothing to being, then existed and developed. At this pioneering stage, each institution or organization is still in a weak condition, because the necessary organizational components are not yet available in full. In addition there is no strong organizational culture so that the mechanism of action is still dependent on the personal actions of the leadership. This weakness is especially in the face of very pressing external challenges.

In the still weakness condition of the KPK did not make it possible to carry out larger enforcement actions (Investigations, investigations and prosecutions). That is why Taufiequrachman Ruki's leadership achievement in the field of enforcement is still low quantitatively.

The direction of Taufiqurrahman Ruki's leadership is to establish the KPK organization in accordance with the provisions of Law No. 30/2002 and to complete the organizational structure and recruit human resources and train them to become professional functional personnel. In addition Taufiequrachman Ruki must find and prepare the technology needed to support the smooth execution of the duties and authorities of the KPK.

With the success of Taufiqurrahman Ruki's leadership in building the KPK's organization, it has prepared the conditions needed by the leadership of the KPK for the next period to carry out its tasks better, in the field of anti-corruption law enforcement (investigation, investigation and prosecution).

The pioneering formation of the KPK organization was designed to be a professional and visible organization to apply the principles of good governance. To achieve this the short-term goal of pioneering is set out to include four things, namely (a) the formation of an organizational structure; (b) recruiting HR and placing it in the organizational structure and conducting functional education according to the needs of the tasks and functions; (c) preparing and preparing software such as Vision-Mission, Principle, work mechanism, code of ethics; (d) Preparation of work facilities and infrastructure such as information technology devices and sophisticated tapping technology.

\subsection{Establishing the KPK organization}


In this case the structure includes a complete structure in accordance with Law number 30 of 2002, especially article 21 which regulates structural positions in accordance with their duties and authorities. This provision was implemented by the leadership by issuing the Decree of the Head of the Corruption Eradication Commission Number 7 / KPK / II / 2004 concerning the Organization of the Corruption Eradication Commission, which was compiled by placing four main areas of organizational structure of the Corruption Eradication Commission, namely the Institutional Development Sector, Prevention Sector, Enforcement Sector and Community Participation Sector. These four areas are the core of Chapter I regarding Place, Responsibility and Organizational Structure, which is regulated by Law Number 30 of 2002 concerning the KPK.

\subsection{Prepare human resources}

When the first period of the KPK leadership was inaugurated on December 29, 2003 by President Megawati Soekarnoputri, there were only five people owned by the KPK at that time. It was only at the beginning of 2004, based on Presidential Decree number 46 of 2004 concerning the transfer of the organization of the State Administering Commission on the Prosecutor's Wealth (KPKPN), the KPK obtained an abundance of employees from the KPKPN. The KPKPN was integrated into the KPK institution and the KPKPN disbanded because its functions and tasks were taken over by the KPK. During 2004 the KPK filled its structural positions, starting on May 17, ending on December 31, 2004, recruiting 4 deputies and 12 directors. This recruitment process is assisted by an independent consultant. Whereas the Secretary General was appointed by President Megawati on August 31, 2004. At the end of 2004 the KPK had 125 people. This number expanded to 150 people in 2005 , and more than doubled in 2006 to 314 people. And in the last year of the leadership term of this first period, increased $50 \%$ to 450 people (KPK, 2014).

Not just recruiting employees, the KPK is also preparing the human resources it has recruited to get competency improvement training in the field of corruption eradication. During 2004, there were 10 times education and training, consisting of 29 Investigators' Training and Education, attended by 29 KPK investigators. This training and education was held in collaboration with the National Police, held once.

In addition, the KPK also sent its staff to attend training, seminars and education in the field of Information Technology competencies, held 9 times with different themes.

\subsection{Develop and prepare software}

The five types of KPK organization software are formulated and agreed upon together. Everyone feels involved and involved in organizing themselves. So as to create a strong spirit atmosphere towards the KPK organization. These five things are very important for the KPK as a first step in shaping the direction of the KPK's goals as well as the initial formation of the culture of the KPK organization.
Taufiequrachman Ruki's achievement has been able to accelerate the development stage of the KPK organization from nothing to nothing with the development of software and hardware within the KPK institution, even the formation of a collective leadership format as expected in article 21 (5) of Law number 30 of 2002. This initial stage of development is the stage of interaction between leaders and subordinates who mutually evaluate the motives and attitudes of each resource, the potential to be united and the development of a shared role. The short leadership of Taufiequrachman Ruki has been able to show and unite the individual motives of its members in the KPK organization into one hope and a shared role towards achieving organizational goals. Taufiequrachman Ruki's achievement surpasses what Yukl said that the initial stage of achieving a clear form of leadership requires a relatively long time (Yuki, 2007).

It can be said that Taufiequrachman Ruki has been able to form an institution and collective leadership based on 3 dimensions, namely (a) the dimension of collective decisions, namely familiarizing and institutionalizing the decision-making process by involving all members of the leadership, (b) the dimension of togetherness in working by involving all structures and functional groups, (c) team-based operational dimensions. The implementation of the decision is carried out in the form of operational activities carried out by a team-based functional group.

The formation and development of the KPK organization had been started by the leadership of Ruki after the hardware was fulfilled and completed as needed to support the formal duties and authority of the KPK. Along with that slowly but surely built organizational software such as (a) employee code of ethics; (b) code of conduct of leadership; (c) organizational institutional structure; (d) staffing rules; (e) work guidelines; (f) standard operational procedures; (g) technical competency standards; and (h) Standards of behavioral competence.

The eight KPK organizational software became the basis for the development of collective leadership, namely leadership that is typical of the KPK and not yet in state institutions or in Indonesian government agencies. Since the completion of this software, the KPK organization has moved towards the formation of a strong collective leadership format.

Antasari Azhar Era (207-2011) is an era of leadership that is in a situation of "testing the operationalization of a collective leadership format" in carrying out the duties and authorities of corruption enforcement. It is said so because in the era of its leadership the KPK moved to implement anti-corruption laws by taking action against corruption cases. This is possible because the KPK organization already has the software and hardware to exercise its authority in prosecuting corruption cases.

Antasari Azhar's leadership moves in a format of collective leadership that had been built by the previous KPK chairman who based his mechanism on these three (3) dimensions. In each action plan Antasari emphasizes collective decision making involving all parts of the related structure, namely all deputies, all directorates 
and all task forces. There is no dominant part in determining a decision. All parts supply data to each other so as to create an atmosphere of mutual understanding. With decisions made together, then all are responsible for these decisions. This is what is meant by the mechanism of collective leadership based on the Collective Decision Dimension.

After the collective decision-making process runs optimally, there is a psychological atmosphere in which each person involved in collective decision- making feels that they are part of an organization that is struggling to eradicate corruption. This pride fosters the behavior of togetherness at work and does not compete between individuals or between sections by highlighting themselves or their parts. This is the meaning of the Togetherness Dimension, which produces a work ethic of togetherness between the KPK's organizational sections.

When the results of collective decisions will be carried out in the operation of action, both in the operation of investigation, investigation, and prosecution all the parts support by giving the data, personnel, and strategies required by the task force working in the field. There are three types of task forces (Task Force), the Investigation Task Force, the Investigation Task Force, and the Prosecution Task Force. Three Task Force are in the structure of Deputy for Enforcement. In other words the operationalization of decisions in the field involves all structural elements of the KPK as a team unit. This is the dimension of team-based operationalization, which is a consequence of the atmosphere of togetherness created by the collective decision-making process.

With the mechanism of collective leadership as above, the KPK is increasingly able to show its achievements in prosecuting corruption perpetrators. Since January 2008 the KPK has been carrying out enforcement actions against high-ranking officials suspected of committing criminal acts of corruption. One of them set the former Kapolri Rudiharjo as a corruption suspect in an immigration fee of Rp.2.2 billion while serving as ambassador to Malaysia.

Furthermore, in February 2008 the KPK named Bank Indonesia Governor Burhanuddin as a suspect of misuse of funds from the Indonesian Banking Development Foundation (YPPI) worth Rp. 100,000 billion. The following month, in March 2008 the KPK won a prosecutor from the Attorney General's Office named Urip Tri Gunawan for receiving a bribe from Artalita Suryani worth US $\$ 660,000$ to pass a businessman Syamsul Nursalim over the misappropriation of Bank Indonesia Liquidity Assistance (BLBI) funds.

KPK Chairperson Antasari Azhar is increasingly named as an anti- corruption fighter after in October 2008 named President Susilo Bambang Yudhoyono's inlaw as a suspect of corruption, namely Aulia Pohan, who must take responsibility for the misappropriation of YPPI funds (Yuwono, 2018).

With the leadership of Antasari Azhar who dared to arrest several big-time corruptors, it brought KPK to be more trusted by the public. And Antasari has proven that he is not a corrupt collaborator as has been exhaled by anti-corruption activists. Even Antasari Azhar's achievements have been able to double ten times the success of the previous KPK leadership. With its success in saving the country's assets worth 36.5 million US dollars, and the KPK investigation, it increased significantly to 43 cases handled during 2008 (Yuwono, 2018).

Even up to 2009 Antasari Azhar was able to improve his achievements by saving state losses of Rp. 134.7 billion and saved state assets worth Rp.152.9 trillion and the corruption cases handled increased to 135 cases. The KPK's performance was very impressive under the leadership of Antasari Azhar and succeeded in increasing public trust in the KPK.

However, with the success of Antasari Azhar arresting high-level corruptors, resulted in a counterattack. Moreover, while he was the Chair of the KPK, Antasari Azhar still carried on the habit of a loose prosecutor's office in implementing the professional code of ethics. Antasari Azhar had violated the KPK leadership code of conduct which prohibits playing golf. His involvement in the golf course took Antasari Azhar to be trapped in the murder of the director of PT. Putra Rajawali Banjaran, Nasrudin Zulkarnaen. The network of corruptors who are worried about the KPK's ability to eradicate corruption apparently has targeted and set traps for Antasari Azhar. Although the judicial process has many irregularities, Antasari has not escaped the charges of murder and was sentenced to 17 years in prison. In addition, when examined at the National Police Headquarters, Antasari Azhar claimed that a number of KPK leaders received bribes from Anggoro, Director of PT. Masaro Radiocom is involved in a corruption case. As a result, other KPK leaders were examined by the National Police headquarters and two KPK leaders as suspects, namely Chandra M. Hamzah and Bibit Samad Rianto who were suspected of extortion and abuse of authority. As a result, the leadership process at the KPK was slow, and finally President Susilo Bambang Yudhoyono replaced Antasari Azhar with Tumpak Hatorangan as Acting Chairman of the KPK (October 2009 - March 2010). Then it was determined that the Chairperson of the KPK had a positive replacement for Antasari Azhar, M. Busyro Muqoddas (2010-2011).

Although Antasari Azhar's leadership period lasted only briefly, since Tuesday December 18, 2007 President Soesilo Bambang Yudhoyono was installed, and was dismissed on October 11, 2009 with Presidential Decree number 78/P- Year 2009, because Antasari was detained by the police for alleged involvement in murder .

Although the life of Antasari Azhar's leadership only lasted around 23 months, success in the handling of corruption cases was very successful, as can be seen in Table 1. KPK leadership was continued by Abraham Samad (2007-2011). This era is a period of strengthening the mechanism of collective leadership that has been built since the beginning of the Commission established and developed by the leadership of Antasari Azhar.

Abraham Samad along with four new KPK leadership members discovered the fact that the KPK's 
collective leadership mechanism inherited by the two previous leadership periods had demonstrated a high level of effectiveness by relying on 3 dimensions, namely the collective decision dimension, the togetherness dimension, and the team-based operational dimension.

Although the KPK has a strong foundation for collective leadership, Abraham Samad sees a lack of clear direction in the eradication of corruption, both in the short and long term. That is why the leadership of Abraham Samad immediately invited all sections and all KPK employees to formulate the KPK Road Map 20011-2023.

Table 1 Data of Corruption captured by Antasari Azhar

\begin{tabular}{|c|c|c|c|}
\hline No & Institution & Level & Corruptors \\
\hline 1 & $\begin{array}{l}\text { National } \\
\text { Legislators }\end{array}$ & National & 40 \\
\hline 2 & Ministers & National & 8 \\
\hline 3 & Ambassadors & National & 4 \\
\hline 4 & Judges & National & 4 \\
\hline 5 & Attorney & National & 4 \\
\hline 6 & Advocates & National & 2 \\
\hline 7 & $\begin{array}{l}\text { National } \\
\text { Commissions }\end{array}$ & National & 6 \\
\hline 8 & Banking & National & 5 \\
\hline 9 & $\begin{array}{l}\text { Government } \\
\text { officials }\end{array}$ & $\begin{array}{l}\text { National/ } \\
\text { Reg/ } \\
\text { Local }\end{array}$ & 50 \\
\hline 10 & Governors & Regional & 8 \\
\hline 11 & Regents / Mayors & Local & 26 \\
\hline & Total & & 187 \\
\hline
\end{tabular}

Source: KPK Annual Report 2008-2009 and various sources

In the Road Map document, three phases of corruption eradication were agreed. Phase One lays the foundation of national integrity $(2011-2015)$ by handling major corruption cases (Grand Corruption). The Second Phase applies the National Integrity System (2015-2019). The second phase is carried out with action against major corruption cases, especially against the Executive, Legislative and Judiciary, the usaaha world, and the Madani community.

The third phase, the creation of a culture of integrity (2019-2023). The culture of integrity is implemented by optimizing the handling of corruption cases in the strategic sector, and optimizing the national integrity system for the Executive, Legislative and Judiciary, the business world, and the Madani community. In this third phase, Indonesia is expected to be free from corruption and the role of the KPK will shift as a stimulus to government and state institutions to implement a Good Internal Control System (SPI) and Government Internal Control System (SPIP) (KPK, 2014).

The involvement of all KPK components in the Road Map formulation process has increased the feeling of togetherness higher, and led to a situation where everyone at the KPK felt an important part of the struggle to achieve the target of corruption-free Indonesia in 2023 as stated in the Road Map. The work situation which is filled with a high atmosphere of togetherness is a form of dimension of cohesiveness that has been added by the leadership of the era of Abraham Samad. Thus the KPK's collective leadership has developed more steadily. The stability of the KPK's collective leadership mechanism will be directly proportional to the performance contributed by all sections and all employees to the KPK institution as an institution for eradicating corruption, as can be seen in Table 2.

Table 2 Development of KPK's Performance in Acting Corruption Cases 2003-2015

\begin{tabular}{|c|c|c|c|}
\hline $\begin{array}{c}\text { Leadership Era / } \\
\text { Repression }\end{array}$ & $\begin{array}{c}\text { Taufiequrachman } \\
\text { Ruki Era } \\
(2003-2007)\end{array}$ & $\begin{array}{c}\text { Antasari Azhar } \\
\text { Era } \\
(2007-2011)\end{array}$ & $\begin{array}{c}\text { Abraham } \\
\text { Samad } \\
\text { Era } \\
(2011-2015) \\
\end{array}$ \\
\hline Pre- Investigation & 152 cases $/ 100 \%$ & 269 cases $/ 177 \%$ & $\begin{array}{l}325 \text { cases } \\
/ 214 \%\end{array}$ \\
\hline Investigation & 76 cases $/ 100 \%$ & 226 cases $/ 297 \%$ & $\begin{array}{l}375 \text { cases/ } \\
493 \%\end{array}$ \\
\hline Prosecution & 53 cases $/ 100 \%$ & 204 cases $/ 385 \%$ & $\begin{array}{l}308 \text { cases } \\
/ 581 \%\end{array}$ \\
\hline $\begin{array}{l}\text { Court } \\
\text { Judgment }\end{array}$ & 40 cases $/ 100 \%$ & 141 cases $/ 353 \%$ & $\begin{array}{l}148 \text { cases } \\
1370 \%\end{array}$ \\
\hline
\end{tabular}

An increase in performance in the era of Abraham Samad's leadership as a result of the development of the mechanism of collective leadership with an additional dimension of cohesiveness. This cohesiveness is a development of the dimension of togetherness which was successfully triggered by leadership actions in the form of involving all KPK components in the formulation of the Road Map, as well as the presence of the Road Map itself is a completeness factor of the togetherness dimension.

Cohesiveness is a level where a group works with a high commitment to stay together. Group cohesiveness comes from influential forces on members to remain in the group. The forces that create cohesion include (a) attractiveness to the group; (b) the impossibility of leaving the group; and (c) motivation to remain a group member.

The three forces put forward by Moorhead and Griffin are owned by KPK members, namely the idealism of corruption eradication that is owned by every member of the KPK inspired by the 1998 reform struggle that succeeded in overthrowing the authoritarianism of President Soeharto's government. This idealism is developing in the community, especially among reform activists to develop Indonesia without corruption in the future.

In the idealism of eradicating corruption has produced a strong spirit of cohesiveness to remain a member of the KPK. In this case, the KPK is a place that accommodates idealistic anti-corruption people. In other words, the attraction towards the group arises and develops within the KPK institution because of the similarity of ideals and perceptions that are relatively similar in describing Indonesia's future without 
corruption that has been formulated in the Road Map. The position of the Road Map and the process of joint involvement in its formulation occupy a very important position in increasing the cohesiveness of all parts of the KPK. So that they are happy to remain in the KPK institutional group. This is the attraction of the KPK for its members. In other words the KPK has been able to become a forum for people who want to fight for the eradication of corruption, even though they each departed from relatively different backgrounds.

The three spirits above are marked by the willingness of all KPK members to prioritize organizational goals rather than personal interests. This happens because individual goals have been fulfilled with conducive interactions, cohesive, and a spirit of pride as people who strive for the good of the nation towards a corruption- free in Indonesia.

\section{Discussion and conclusion}

The leadership mechanism applied by the KPK was formed in 3 development cycles that proceeded during the initial journey up to three times the leadership period, namely the pioneering cycle, the critical cycle, and the stabilization cycle.

The pioneering cycle is characterized by leadership actions in the procurement and preparation of the hardware and software needed as each newlyestablished organization requires a set of tools and internal regulations that determine work mechanisms and work ethics.

The second cycle is a critical cycle. In this cycle the leadership mechanism begins to be implemented based on 3 (three) dimensions of leadership, namely (a) Dimensions of collective decision making (b) Dimensions of togetherness in organizational actions, and (c) Dimensions of operationalization of team-based decisions. Thus, it is called collective leadership if the mechanism that is implemented by accommodating the decision making process collectively involves all the parts in the organizational structure without any dominant party. This decision making process is based on a shared motivation at work, and the results of the decision are carried out by a group of teambased implementers. This second cycle is called a critical cycle because its implementation is trial and error and faces threats from external parties that lead to efforts to eliminate KPK leadership.

And in the end the KPK's collective leadership developed in the third cycle, namely the consolidation cycle which was marked by the presence of a clear vision dimension as the giver of the direction of the KPK's organization into the future. The vision dimension is proven to increase high cohesiveness among individuals in supporting the life of the KPK as an institution that wants to build a corruption-free Indonesia in 2023.

And finally the performance produced by the KPK's 4-dimensional collective leadership mechanism tends to be superior, which results in multiples of performance 5 to 10 times more than before.

\section{References}

Archer, D, \& Cameron, A, (2009). Collaborative Leadership, How to Succeed In An Interconnected World, Elsevier, Ltd.

Crutchfield, L., \&, Grant, M, (2010), Share Leadership, in Perry, James L,(Ed), The Jossey-Bass Reader On Non Profit And Public Leadership, John Wiley \& Son, Inc

Ebegbulem, C. (2012). Corruption and Leadership Crisis in Africa. Nigeria: Nigeria in Focus.

Friedrich, et al., (2009). A Framework for Understanding Collective Leadership: The Selective Utilization of Leader and Team Expertise within Networks, in The Leadership Quaterly, 1(1) 4-7.

Kartono, K. (2013). Pemimpin dan Kepemimpinan Abnormal itu? Raja Grafindo Persada.

KPK (2014). Laporan Tahunan Komisi Pemberantasan Korupsi Tahun 2004-2014, Jakarta. KPK.

Pasolong, H. (2010). Kepemimpinan Birokrasi, Alfabet.

Rivai, R. \& Wahyudi, D. (2011). Kepemimpinan dan Perilaku Organisasi, Raja Grafindo Persada.

Robbins, P. (2002). Prinsip-Prinsip Perilaku Organisasi. Jakarta: Erlangga.

Yuki, G. (2007), Kepemimpinan Dalam Organisasi. Indeks. 